\title{
MIR132 wt Allele
}

National Cancer Institute

\section{Source}

National Cancer Institute. MIR132 wt Allele. NCI Thesaurus. Code C82080.

Human MIR132 wild-type allele is located in the vicinity of $17 p 13.3$ and is 100 bases in length. This allele, which encodes MIR132 pre-miRNA, plays a role in the regulation of gene expression. Alteration in the expression of this gene is associated with the development of Huntington's disease. 